\title{
Comparative evaluation of microbiological and nutritional qualities of various cereal-based paps $(O g i)$ in Ondo State, Nigeria
}

\author{
Olorunjuwon O. Bello ${ }^{1}$, Temitope K. Bello ${ }^{2}$, Olumayowa T. Amoo ${ }^{1}$ and YisauO. Atoyebi ${ }^{3}$
}

\author{
${ }^{1}$ Department of Biological Sciences, College of Natural and Applied Sciences, Wesley University Ondo, Nigeria \\ ${ }^{2}$ Department of Biological Sciences, Faculty of Pure and Applied Sciences, Southwestern University Nigeria \\ ${ }^{3}$ Department of Chemical Sciences, Faculty of Science, Olabisi Onabanjo University, Ogun, Nigeria
}

\begin{abstract}
This study was carried out to determine the microbiological, proximate and elemental analyses of maize-, millet- and sorghum-based Ogi in Ondo State, Nigeria. Samples were monitored at points of preparation from 0 to 96 hours of fermentation. Selected dilutions were inoculated by spread-plate method on appropriate medium for isolation of aerobic bacteria, staphylococci, enterobacteria, lactic acid bacteria (LAB) and fungi. Further identification was done by API 50 CHL, API 50 $C H B$ and API 32 ID kits for LAB, aerobic bacteria and fungi, respectively. Proximate and mineral compositions were in accordance to standard procedures. One-sample ttest, paired-wise sample t-test and Analysis of Variance were used to analyze data. The microbial load gradually increased from 0 hour and attained optimum at $24-48$ hours of fermentation, before declining at 72 to 96 hours. LAB were persistent and most predominant. Twenty-four bacterial species were isolated. Occurrence of Lactobacillus plantarum (10.3\%) was highest while Mucor mucedo $(0.86 \%)$ was lowest. There were no significant differences in the microbial loads, proximate and elemental compositions of products.Thisstudy revealed the distribution of fermentative microorganisms and few contaminants which were not directly associated with fermentation process. The study also showed significantly acceptable proximate and elemental compositions of the products.
\end{abstract}

Keywords - Cereals, fermented food, microorganisms, nutritional composition.

\section{INTRODUCTION}

Fermentation technology has lived as long as mankind $[1,2]$. It is, thus, an integral traditional practice in many communities in Africa and other continents of the world. Fermentation of food has been described as age-long culture www.ijeab.com which has been under-documented particularly in West Africa, where absence of writing culture made its origin difficult to trace [3]. Fermentation of food typically involves the application of microorganisms (either from the environment i.e. spontaneous process or inoculated in a controlled environment) that produces certain enzymes which changes the chemical attributes of the food from its original form/state. Fermentation is a desirable biochemical modification process of main food matrix brought about by microorganisms and their associated enzymes [4]. The changes that occur during fermentation could either be deleterious (producing toxins) or beneficial (producing food products with superior or distinct attributes).

The Nigerian indigenous fermented foods constitute a group of foods that are produced in homes, villages and smallscale cottage industries. They are sold to the rural populace who buy them for food and social ceremonies. Roots, legumes, cereals, fruits, oil seeds, nuts, meat, fish, milk and palm tree sap are some of the substrates from which fermented foods are derived. One of the popular indigenous cereal-based fermented foods in Nigeria is $O g i$, a kind of pap, which is a fermented cereal porridge made from maize (Zea mays), sorghum (Sorghum vulgare) or millet (Pennisetum typoideum). Pap can be simply described as a kind of diet that does not require chewing. The cereal-based pap $(\mathrm{Ogi})$ is very smooth in texture and has a sour taste reminiscent of that of yoghurt. Typically, $O g i$ has a distinct aroma and fine texture. The colour of the $O g i$ is mainly depending on the type of feedstock used for the processing. It could either be consumed as porridge (pap) or as a gel-like product (agidi) in some West African countries [5,6].

Sorghum, maize and millet beverages in Africa possess similar features in which the lactic acid bacteria 
fermentation plays a key role in safety and acceptability of these products in tropical climate. Cereal beverages are popular in Africa because of the social, religious and therapeutic values associated with them. The consistency of the pap varies from thick to watery depending on choice. The pap can be sweetened with sugar and milk; it is then eaten with bean cake. The pap is used as the first native food for weaning babies [7,8].

It also serves as breakfast meal for pre-school, school children and adults. In a more concentrated form it is boiled into a thick gel and then allowed to set stiff in leaf moulds as "eko" or "agidi". In either form, it is usually preferred to many other indigenous foods by the aged and the convalescence. The stages of traditional $O g i$ production include: washing of grains, steeping for 3 days at ambient temperature $\left(28 \pm 2{ }^{\circ} \mathrm{C}\right)$, wet-milling, wet-sieving with a hand sieve or muslin cloth with about $300 \mu \mathrm{m}$ pore size and sedimentation/souring of the filtrate for 1-3days. Thereafter, the water is decanted and the wet, clean sediment $(O g i)$ is collected and stored for personal use or sold to consumers in its wet form in small units packaged in leaves or polypropylene bags $[9,10]$.

The traditional method of $O g i$ processing is accompanied by severe microbial contamination and nutrient losses, the magnitude of which depends on the hygienic practices, quality of water, type of cereal grains and the fermentation or souring periods and the milling method used. This study was, therefore, carried out to determine the microbial quality of fermented maize-, millet- and sorghum-based Ogi in Ondo State, Nigeria.

\section{MATERIALS AND METHODS}

\subsection{Sample Collection}

Three samples each of sorghum-, millet- and maize-based $O g i$ were monitored at the points of preparation, from different locations over a period of four days, from zero (0) to 96 hours of fermentation of the cereals within Ondo West Local Government Area. The samples were collected in sterile polythene bags and transported to the laboratory for analysis.

\subsection{Sample Preparation}

Ten grams each of the paste-like samples was weighed and introduced in $90 \mathrm{ml} 0.85 \%$ (w/v) sterile physiological saline and homogenized in a stomacher lab-blender (Panasonic, Model MX-GX1021, China) for $1 \mathrm{~min}$. These were serially diluted to obtain dilution factors of up to $10^{9}$.

2.3Microbiological analysis www.ijeab.com
One mil each of randomly selected dilutionswas prepared on appropriate agar media by spread-plate method for isolation and enumeration of microorganisms. Aerobic bacteria, staphylococci and enterobacteriaceae were cultivated and enumerated on Plate Count Agar (PCA) (Oxoid England), mannitol salt agar (MSA, Oxoid) and MacConkey agar (Oxoid), respectively. Plates were incubated at $30{ }^{\circ} \mathrm{C}$ for $48 \mathrm{hrs}$, morphological characteristics on plates examined and the number of colony forming units (CFU) for each morphotype recorded separately. Potato dextrose agar (SDA, Oxoid) containing $50 \mathrm{mg} / \mathrm{L}$ chloramphenicol and $50 \mathrm{mg} / \mathrm{L}$ chlortetracycline, to inhibit bacterial growth, was employed for the cultivation of fungi. Incubation was at $25^{\circ} \mathrm{C}$ for 3 to 5 days. Lactic acid bacteria (LAB) were grown on de Man Rogosa and Sharpe (MRS) agar (Oxoid) incubated under anaerobic conditions in an Anaerobic Gas-Pack system at $30^{\circ} \mathrm{C}$ for $48-72 \mathrm{~h}$. Colonies were counted and recorded as logarithms of the numbers of colony forming unit per gram (cfu/g). Pure isolates were stocked for further characterization.

\subsection{Identification of isolates}

Bacterial isolates were examined for Gram's reaction, catalase production and sporulation (incubation in nutrient broth plus $50 \mathrm{mg} / \mathrm{l} \mathrm{MnCl} 2$ for 7 days). Presumptive LAB isolates on MRS agar were examined for Gram's reaction, catalase production, gas production from MRS-broth containing inverted Durham tubes [11] and growth at $15^{\circ} \mathrm{C}$ and $45^{\circ} \mathrm{C}$ in MRS broth. Cell morphology and motility were examined by microscopic observation of cells grown in broth for $24 \mathrm{~h}$. Identification of filamentous fungi was carried out following the taxonomical keys of Schipper [12] and Hesseltine [13]. Fermentation and assimilation of carbon compounds were determined using API 50 CHL kits for LAB, API 50CHB kits for aerobic bacteria and API 32 ID kits for fungi according to the manufacturer's instructions (BioMerieux, Marcyl'Etoile, France). The results were recorded visually and analysed by APILAB Plus V3.2.2 software (BioMerieux).

2.5Analysis of Proximate composition

Moisture content was determined by weight loss of 2 $\mathrm{g}$ of sample after heating in an oven (MAXI, Model No. PSC31G2-GI, Turkey) at $105{ }^{\circ} \mathrm{C}$ for 3 hrs. The ash content was measured by heating the sample at $550{ }^{\circ} \mathrm{C}$ until the difference between two successive weights was less than $1 \mathrm{mg}$. Protein content was determined by multiplying total nitrogen, estimated by standard Kjeldahl method by 6.26. Fat content was determined by ether extraction Page | 677 
method using a glass soxhlet. The crude fibre content was determined using fibretec extraction. The carbohydrate content was determined by differences:

$\%$ Carbohydrate $=100-(\%$ Moisture $+\%$ Fat $+\%$ Ash $+\%$ Crude fibre+\% Crude protein).

\subsection{Mineral Composition}

A fraction of $0.3 \mathrm{~g}$ of each of the paste-like sample was wet digested in a $50-\mathrm{ml}$ beaker using $30 \mathrm{ml}$ of $\mathrm{HNO} 3-\mathrm{HClO} 4$ acid solution (2:1 volume) on a hot digestion system to obtain a colourless solution after heating. At the completion of digestion, the solution of each sample was transferred into a 50-ml calibrated sample bottle and the solution was diluted to the mark with distilled water. Calcium $(\mathrm{Ca})$, Magnesium ( $\mathrm{Mg})$, Iron (Fe) and Zinc ( $\mathrm{Zn})$ in the samples were determined by flame atomic absorption spectrophotometer. Sodium $(\mathrm{Na})$ and Potassium $(\mathrm{K})$ in the samples were determined by flame photometer using a working standard of $10 \mathrm{ppm}$ for each of the species [14].

\subsection{Statistical Analysis}

The data obtained were analyzed using statistical onesample t-test, paired-wise sample t-test and Analysis of Variance (ANOVA) at 95\% level of confidence ( $\mathrm{P} \leq 0.05$ ) employing the statistical package for social sciences (SPSS) version 17.

\section{RESULTS}

Table 1 showed microbial load during and after fermentation of maize, millet and sorghum for $O g i$ production in Ondo State, Nigeria. Sorghum-based $O g i$ had the highest aerobic bacteria count of $4.3 \times 10^{5}$ $\mathrm{CFU} / \mathrm{g}$ at zero (0) $\mathrm{h}$ of fermentation which increased to
$1.71 \times 10^{6} \mathrm{CFU} / \mathrm{g}$ at $24^{\text {th }} \mathrm{h}$ of fermentation. However, the aerobic bacteria count started decreasing at the $48^{\text {th }} \mathrm{h}$ and at the $96^{\text {th }} \mathrm{h}$, no aerobic bacteria was detected on the plate count agar medium. This was also the case with maizebased $O g i$ which had aerobic bacteria count of $3.8 \times 10^{5}$ $\mathrm{CFU} / \mathrm{g}$ at the zero (0) $\mathrm{h}$ of fermentation, increased at the $24^{\text {th }} \mathrm{h}$, reduced thereafter and at the $96^{\text {th }} \mathrm{h}$ of fermentation, no aerobic bacterium was detected. The millet-based pap had $3.7 \times 10^{5} \mathrm{CFU} / \mathrm{ml}$ at zero (0) $\mathrm{h}$ with no bacterium detected at the $96^{\text {th }} \mathrm{h}$ of fermentation on PCA medium after following same pattern of growth at $24^{\text {th }}, 48^{\text {th }}$ and $72^{\text {nd }}$ h. Staphylococci counts for the maize-based $O g i$ were $2.5 \mathrm{x}$ $10^{2}, 2.7 \times 10^{2}$ and $1.8 \times 10^{2} \mathrm{CFU} / \mathrm{g}$ at the $0,24^{\text {th }}$ and $48^{\text {th }} \mathrm{h}$ of fermentation, respectively. For the sorghum-based $O g i$, staphylococci counts at the $0,24^{\text {th }}$ and $48^{\text {th }} \mathrm{h}$ of fermentation were $2.3 \times 10^{2}, 3.2 \times 10^{2}$ and $1.1 \times 10^{2} \mathrm{CFU} / \mathrm{g}$, respectively; and $1.8 \times 10^{2}, 2.1 \times 10^{2}$ and $1.3 \times 10^{2} \mathrm{CFU} / \mathrm{g}$ respectively for the millet-based $O g i$. All staphylococci had been eliminated in the sample at the $72^{\text {nd }}$ and $96^{\text {th }} \mathrm{h}$ of fermentation of the three cereal-based $O g i$. The predominant set of microorganisms were the lactic bacteria which kept increasing from the 0 to $96^{\text {th }} \mathrm{h}$ of fermentation. LAB counts ranged from $2.9 \times 10^{4}$ to $2.93 \times$ $10^{8} \mathrm{CFU} / \mathrm{g} ; 2.1 \times 10^{4}$ to $1.67 \times 10^{8} \mathrm{CFU} / \mathrm{g}$ and $2.9 \times 10^{4}$ to $2.01 \times 10^{8} \mathrm{CFU} / \mathrm{g}$ for the maize-, sorghum- and milletbased $O g i$, respectively. Counts of members of family Enterobacteriaceae from maize-, sorghum- and millet based $O g i$ at $0,24^{\text {th }}$ and $48^{\text {th }} \mathrm{h}$ of fermentation were $5.2 \times 10^{2}, 3.7$ x $10^{3}$ and $2.6 \times 10^{2} \mathrm{CFU} / \mathrm{g} ; 4.1 \times 10^{2}, 4.9 \times 10^{3}$ and $1.7 \times$ $10^{2} \mathrm{CFU} / \mathrm{g}$, and $4.8 \times 10^{2}, 4.1 \times 10^{3}$ and $2.6 \times 10^{2} \mathrm{CFU} / \mathrm{g}$, respectively; and fungal counts were $2.7 \times 10^{2}, 3.2 \times 10^{3}$ and $2.1 \times 10^{2} \mathrm{CFU} / \mathrm{g} ; 3.5 \times 10^{2}, 2.8 \times 10^{3}$ and $1.9 \times 10^{2}$ $\mathrm{CFU} / \mathrm{g}$; and $2.2 \times 10^{2}, 2.1 \times 10^{3}$ and $1.5 \times 10^{2}$, respectively.

Table.1: Microbial load during and after fermentation of maize, millet and sorghum for Ogi production in Ondo State, Nigeria

\begin{tabular}{lllllll}
\hline Medium & \multicolumn{5}{c}{ Fermentation period (hours) } \\
& Cereals & 0 & 24 & 48 & 72 & 96 \\
\hline Aerobic bacteria & Maize & $3.8 \times 10^{5}$ & $1.71 \times 10^{6}$ & $2.62 \times 10^{4}$ & $5.4 \times 10^{2}$ & - \\
count (CFU/g) & Sorghum & $4.3 \times 10^{5}$ & $1.08 \times 10^{6}$ & $1.23 \times 10^{4}$ & $3.7 \times 10^{2}$ & - \\
& Millet & $3.7 \times 105$ & $1.12 \times 10^{6}$ & $1.02 \times 10^{4}$ & $4.1 \times 10^{2}$ & - \\
& & & & - \\
Staphylococci count & Maize & $2.5 \times 10^{2}$ & $2.7 \times 10^{2}$ & $1.8 \times 10^{2}$ & - & - \\
(CFU/g) & Sorghum & $2.3 \times 10^{2}$ & $3.2 \times 10^{2}$ & $1.1 \times 10^{2}$ & - & - \\
& Millet & $1.8 \times 10^{2}$ & $2.1 \times 10^{2}$ & $1.3 \times 10^{2}$ & - & \\
& & & & & \\
LAB count (CFU/g) & Maize & $2.9 \times 10^{4}$ & $1.51 \times 10^{6}$ & $2.62 \times 10^{7}$ & $2.71 \times 10^{8}$ & $2.93 \times 10^{8}$ \\
& Sorghum & $2.1 \times 10^{4}$ & $1.43 \times 10^{6}$ & $2.11 \times 10^{7}$ & $1.22 \times 10^{8}$ & $1.67 \times 10^{8}$ \\
& Millet & $2.9 \times 10^{4}$ & $1.31 \times 10^{6}$ & $2.43 \times 10^{7}$ & $1.85 \times 10^{8}$ & $2.01 \times 10^{8}$ \\
Enterobacteriaceae & Maize & $5.2 \times 10^{2}$ & $3.7 \times 10^{3}$ & $2.6 \times 10^{2}$ & - & - \\
count (CFU/ml) & Sorghum & $4.1 \times 10^{2}$ & $4.9 \times 10^{3}$ & $1.7 \times 10^{2}$ & - & - \\
\hline
\end{tabular}




\begin{tabular}{lllllll} 
& Millet & $4.8 \times 10^{2}$ & $4.1 \times 10^{3}$ & $2.6 \times 10^{2}$ & - & - \\
Fungal count & & & & & - \\
$(\mathrm{CFU} / \mathrm{ml})$ & Maize & $2.7 \times 10^{2}$ & $3.2 \times 10^{3}$ & $2.1 \times 10^{2}$ & - & - \\
& Sorghum & $3.5 \times 10^{2}$ & $2.8 \times 10^{3}$ & $1.9 \times 10^{2}$ & - & - \\
\hline
\end{tabular}

Table 2 showed the distribution of microorganisms in fermented maize-, millet- and sorghum-based Ogi in Ondo State, Nigeria. Lactobacillus delbrueckii, Lactobacillus plantarum, Lactobacillus fermentum, Lactobacillus amylovorus, Corynebacterium spp, Staphylococcus aureus, Bacillus subtilis, Saccharomyces cerevisiae, Candida tropicalis and Aspergillus niger were found in the three cereal-based Ogi. Streptococcus lactis and Bacillus licheniformis were present in millet- and sorghum-based
Ogi. Micrococcus luteus, Escherichia coli, Penicillium sp and Fusarium oxysporium were isolated from maize- and sorghum-based Ogi. Aspergillus flavus was encountered in maize- and millet-based Ogi. Lactococcus lactis, Enterococcus faecalis, Pseudomonas alkaligenes and Bacillus cereus were isolated only in maize-based Ogi. Pseudomonas aeruginosa and Mucor mucedo were present in millet-based $O g i$ only. Rhizopus stolonifer was encountered in only sorghum-based $O g i$.

Table.2: Distribution of microorganisms in fermented maize-, millet- and sorghum-based Ogi in Ondo State, Nigeria

\begin{tabular}{|c|c|c|c|}
\hline Microorganisms & Maize-based $O g i$ & Millet-based $O g i$ & Sorghum-based $O g i$ \\
\hline Lactobacillus delbrueckii & + & + & + \\
\hline L. plantarum & + & + & + \\
\hline L. fermentum & + & + & + \\
\hline L. amylovorus & + & + & + \\
\hline Lactococcus lactis & + & - & - \\
\hline Streptococcus lactis & - & + & + \\
\hline Enterococcus feacalis & + & - & - \\
\hline Pseudomonas aeruginosa & - & + & - \\
\hline Pseudomonas alkaligenes & + & - & - \\
\hline Corynebacterium spp & + & + & + \\
\hline Escherichia coli & + & - & + \\
\hline Micrococcus luteus & + & - & + \\
\hline Staphylococcus aureus & + & + & + \\
\hline Bacillus subtilis & + & + & + \\
\hline B. cereus & + & - & - \\
\hline B. licheniformis & - & + & + \\
\hline Saccharomyces cerevisiae & + & + & + \\
\hline Candida tropicalis & + & + & + \\
\hline Rhizopus stolonifer & - & - & + \\
\hline Aspergillus niger & + & + & + \\
\hline Aspergillus flavus & + & + & - \\
\hline Penicillium sp & + & - & + \\
\hline Mucor muсеdo & - & + & - \\
\hline Fusarium oxysporium & + & - & + \\
\hline
\end{tabular}

Figure 1 showed percentage occurrence of microorganisms associated with fermented maize-, millet- and sorghumbased $O g i$ in Ondo State, Nigeria. Twenty-four (24) bacterial species were isolated from the cereal-based food. Lactobacillus plantarum had the highest percentage frequency of $10.3 \%$, followed by Lactobacillus fermentum (7.73\%), Corynebacterium spp (7.3\%), L. amylovorus (6.87 \%), Lactococcus lactis (6.87\%), Streptococcus lactis (6.01\%), Saccharomyces cerevisiae (6.01\%), Lactobacillus delbrueckii (5.15\%), Candida tropicalis (5.15\%), S. aureus (4.72\%), Rhizopus stolonifer (4.29\%), Micrococcus luteus $(3.43 \%)$, B. licheniformis (3.43\%), Enterococcus faecalis $(2.58 \%)$, B. subtilis $(2.58 \%)$, Penicillium sp $(2.58 \%)$, Fusarium oxysporium (2.58 \%), P. aeruginosa (1.72\%), E. coli $(1.72 \%)$, A. flavus $(1.72 \%)$, B. cereus $(1.29 \%)$ while Mucor mucedo $(0.86 \%)$ had the lowest percentage occurrence. 
12

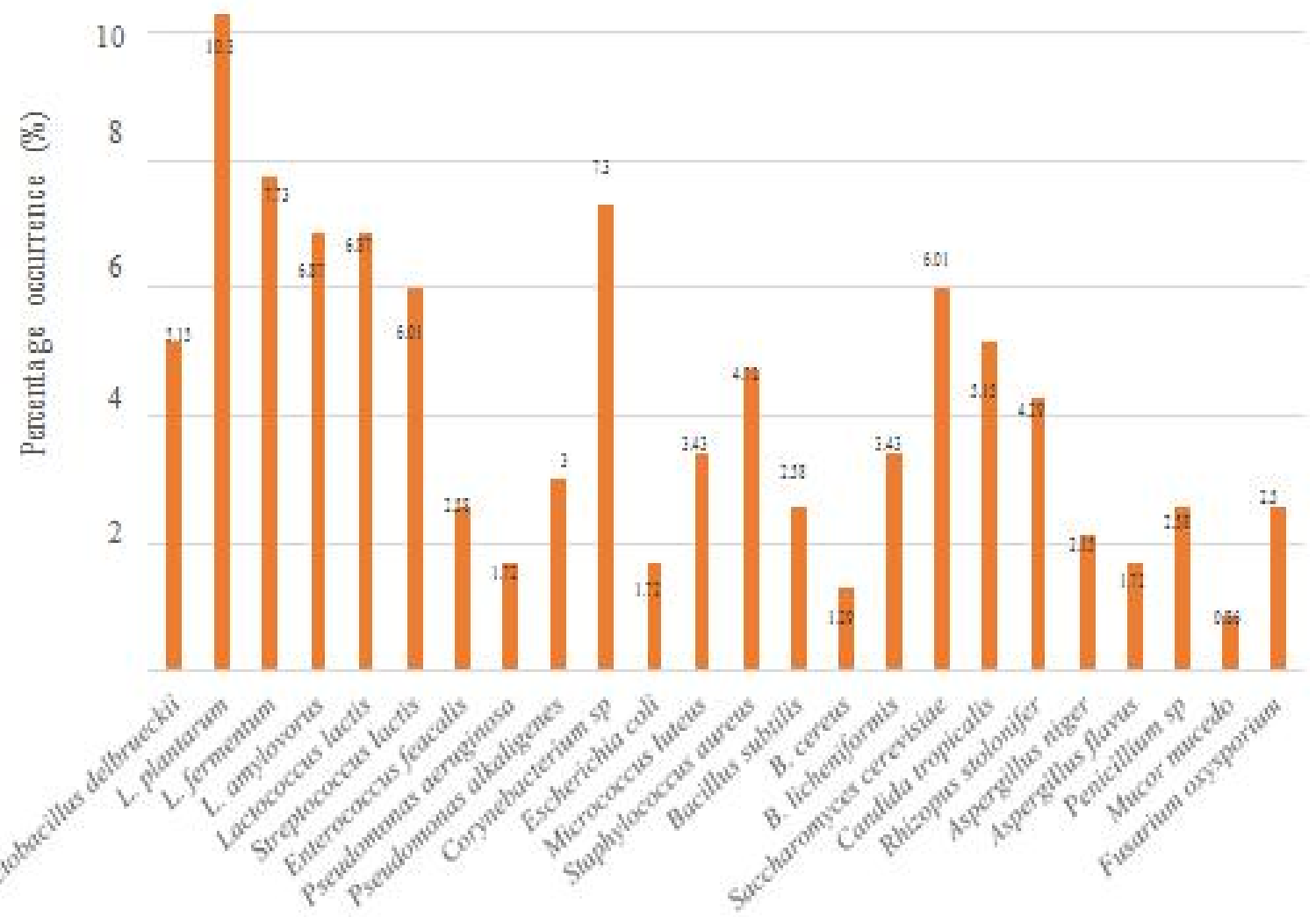

Fig.1: Percentage occurrence of microorganisms associated with fermented maize-, millet and sorghum-based pap (Ogi) in Ondo State, Nigeria

The proximate composition (\%) of fermented maize-, millet- and sorghum-based $O g i$ in Ondo State, Nigeria was shown in Figure 2. Carbohydrate (starch) was present in the three cereal-based $O g i$ in quantities higher than any other. Sorghum-based $O g i$ had the highest $\%$ of carbohydrate $(74.89 \pm 0.671) \%$, followed by maize-based (74.43 \pm $0.050) \%$ and millet-based $O g i(71.30 \pm 0.326) \%$. The $\%$ moisture contents in maize-, millet- and sorghum-based pap were $(9.22 \pm 0.140) \%,(7.98 \pm 0.005) \%$ and $(7.11 \pm 0.004)$ $\%$ respectively; \% protein contents were $(9.01 \pm 0.002) \%$, $(12.11 \pm 0.002) \%$ and $(11.45 \pm 0.040) \%$ respectively while the $\%$ fat compositions were $(2.54 \pm 0.040) \%$, (2.32 $\pm 0.040) \%$ and $(2.42 \pm 0.035) \%$ respectively. The $\%$ fibre compositions of fermented maize-, millet- and sorghumbased $O g i$ were $(3.03 \pm 0.040) \%,(3.76 \pm 0.030) \%$ and $(2.15 \pm 0.050) \%$ respectively while the $\%$ ash contents were $(1.77 \pm 0.020) \%,(2.53 \pm 0.006) \%$ and $(1.98 \pm 0.005)$ $\%$ respectively. There were no statistical differences among the three cereal-based $O g i$ in relation to the percentage compositions of moisture, protein, fat, fibre, ash and carbohydrate $(\mathrm{P}<0.005)$. 


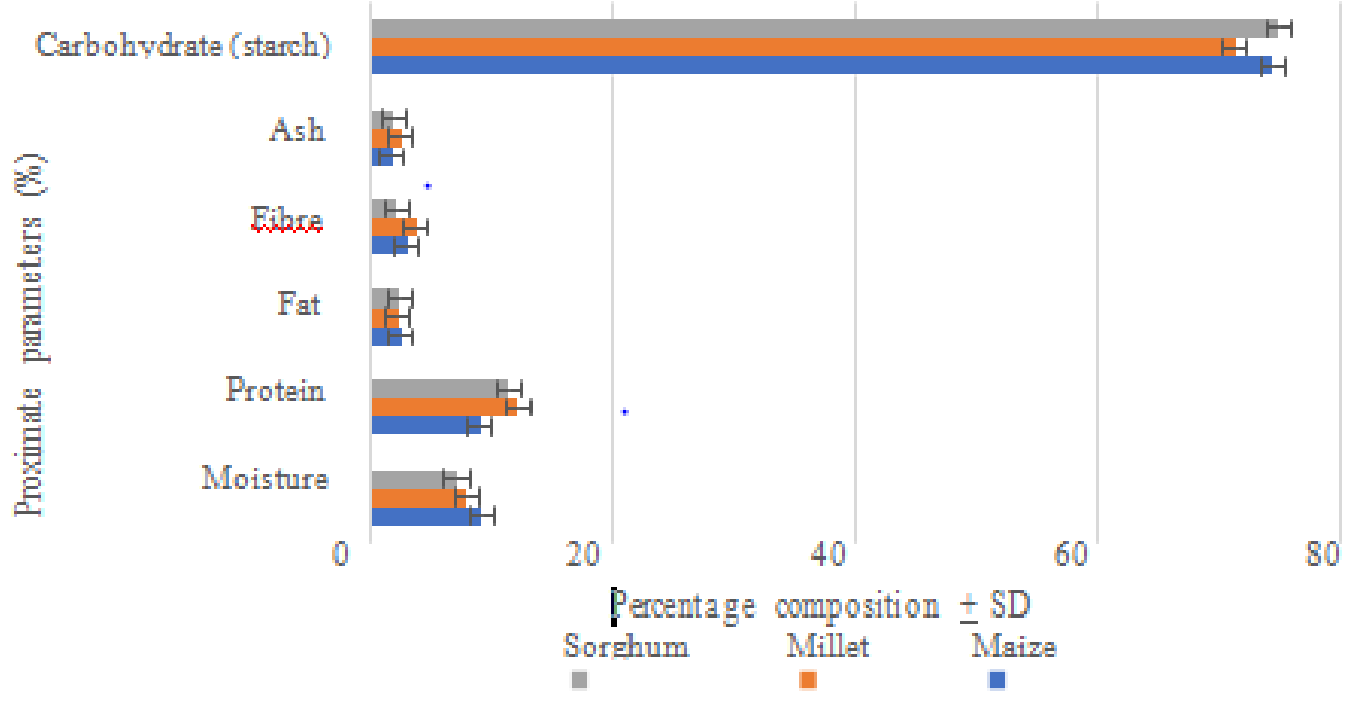

Fig.2: Proximate composition (\%) of fermented maize-, millet- and sorghum-based pap (Ogi) in Ondo State, Nigeria. Values represent means of data $+S D$. Data was statistically analyzed at $95 \%$ level of confidence $(P<0.05) . S D=$ Standard deviation

Table 3 showed mineral compositions ( $\mathrm{mg} / 100 \mathrm{~g}$ ) of fermented maize-, millet- and sorghum-based pap (Ogi) in Ondo State, Nigeria. The calcium (Ca) compositions of fermented maize-, millet- and sorghum-based pap were 14.01, 10.11 and $28.92 \mathrm{mg} / 100 \mathrm{~g}$ respectively. The Zinc $(\mathrm{Zn})$, Sodium $(\mathrm{Na})$, Iron $(\mathrm{Fe})$, Magnesium $(\mathrm{Mg})$ and Potassium (K) compositions in the three cereal-based $O g i$ ranged from 7.87 to $9.72 \mathrm{mg} / 100 \mathrm{~g}, 302.37$ to 352.33 $\mathrm{mg} / 100 \mathrm{~g}, 45.77$ to $52.63 \mathrm{mg} / 100 \mathrm{~g}, 80.01$ to 99.33 $\mathrm{mg} / 100 \mathrm{~g}$ and 310.20 to $426.08 \mathrm{mg} / 100 \mathrm{~g}$, respectively. There was no statistical difference in $\mathrm{Ca}$ composition between maize- and millet-based Ogi $(\mathrm{P}>0.05)$ but the compositions of the former two were significantly different from sorghum-based Ogi $(\mathrm{P}<0.05)$. Composition of $\mathrm{Zn}$ in maize-based $O g i$ was statistically different from millet- and sorghum-based $O g i$ while the latter two showed no statistical difference. There were also significant differences in compositions of $\mathrm{Na}, \mathrm{Mg}$ and $\mathrm{K}$ among the three cerealbased $O g i$. There were no statistical differences between $\mathrm{Na}$ and $\mathrm{Mg}$ compositions in the three cereal-based $O g i$ and their recommended values $(\mathrm{t}=2.007, \mathrm{P}=0.183$ and $\mathrm{t}=2.646, \mathrm{P}$ $=0.118$, respectively).

Table.3: Mineral composition ( $\mathrm{mg} / 100 \mathrm{~g}$ ) of fermented maize-, millet- and sorghum-based pap (Ogi) in Ondo State, Nigeria

\begin{tabular}{lllllll} 
Cereal & $\mathrm{Ca}$ & $\mathrm{Zn}$ & $\mathrm{Na}$ & $\mathrm{Fe}$ & $\mathrm{Mg}$ & $\mathrm{K}$ \\
& & \multicolumn{6}{c}{$\begin{array}{c}\text { Mean of data }+ \text { Standard deviation } \\
\text { Maize-based }\end{array}$} & $14.01^{\mathrm{a}} \pm 0.090$ & $7.87^{\mathrm{a}} \pm 0.002$ & $302.37^{\mathrm{a}} \pm 0.001$ & $52.63^{\mathrm{a}} \pm 0.001$ & $80.01^{\mathrm{a}} \pm 0.005$ & $310.20^{\mathrm{a}} \pm 0.001$ \\
Millet-based & $10.11^{\mathrm{a}} \pm 0.003$ & $9.72^{\mathrm{b}} \pm 0.002$ & $352.33_{\mathrm{b}} \pm 0.002$ & $49.22^{\mathrm{a}} \pm 0.001$ & $99.33^{\mathrm{c}} \pm 0.003$ & $350.66^{\mathrm{b}} \pm 0.001$ \\
Sorghum-based & $28.92^{\mathrm{b}} \pm 0.003$ & $9.28^{\mathrm{b}} \pm 0.002$ & $321.04^{\mathrm{c}} \pm 0.002$ & $45.77_{\mathrm{a}} \pm 0.001$ & $95.97^{\mathrm{b}} \pm 0.004$ & $426.08^{\mathrm{c}} \pm 0.001$ \\
Recommended & 60.00 & $>3.20$ & 296.00 & $>16.00$ & 76.00 & 516.00 \\
value & & & & &
\end{tabular}

Values represent means of data. Mean values with the same superscript along same column had no statistical difference. Level of confidence $=95 \%(\mathrm{P}<0.05)$

\section{DISCUSSION}

Microorganisms play both essential and deleterious roles in food products. In the fermentation industry, the attributes of the food products produced is largely due to the type, age, composition of the microorganisms employed. To a large extent, both population and diversity play a role in the fermentation of products. Table 1 showed microbial load during and after fermentation of maize, millet and sorghum 
for $O g i$ production in Ondo State, Nigeria. The microbial load gradually increased from the first day ( 0 hour) and attained optimum at $24-48$ hours of fermentation, before beginning to decline from 72 to 96 hours. The density of the microbes for lactic acid bacteria culture using MRS agar is second to aerobic culture [15]. This suggests that lactic acid bacteria play a significant role in the fermentation of grains in $O g i$ production.

The population of microbes of the Enterobacteriaceae family was low during fermentation of grains used for the preparation of $O g i$. These groups of microorganisms that grow on MacConkey agar medium including E. coli and Enterococcus faecalis, isolated in this study, do not normally participate in fermentation process. A significant reduction in the growth of E. coli and Klebsiella aerogenes towards the end of fermentation has been reported by Oyelana and Coker [16]. Hence, their occurrence in fermentation medium of the grains, under study for $O g i$ production, could result from the water used for fermentation or as normal flora of the grains prior to fermentation. This also explains the presence of $S$. aureus in the medium at the beginning of fermentation. S. aureus is ubiquitous, and as a normal flora of the skin and nasal cavity of man, it might have been unhygienically introduced during washing of grains and other activities which led to its introduction as contaminant.

The fungal load ranged from $1.5 \times 10^{2}$ to $3.2 \times 10^{3} \mathrm{CFU} / \mathrm{g}$, being far lesser than the population of lactic acid bacteria and general aerobic viable counts. This suggests that most of the microbes that participate in the fermentation of grains for $O g i$ production are mainly bacteria, despite the fact that some yeast also participate actively in the fermentation process [15]. The differences in population of the various classes of microbes (i.e. lactic acid bacteria, aerobic bacteria, family of Enterobacteriaceae, and fungi) could be connected to the acidic nature of the medium. It has been previously reported by various authors that as fermentation proceeds the acidity of the medium increases $(\mathrm{pH}$ tending towards 0 ) and the titratable acidity is enhanced [17].

This is, however, as a result of continual increase in population of lactic acid bacteria throughout the fermentation process. LAB usually turn medium acidic and, thus, antagonizes the occurrence or proliferation of other groups of microorganisms. This explains the gradual decrease in microbial load and elimination of the aerobic bacteria, staphylococci, enterobacteria and fungi during fermentation process in this study. This is supported by the study of Adesokan et al. [18] who reported that this trend could lead to production of lactic acid bacteria that are responsible for fermentation of $O g i$.

The distribution of microorganisms associated with fermentation of different grains for $O g i$ production was shown in Table 2 while Figure 1 showed percentage occurrence of the microorganisms. Basically, different microbes tolerate acid medium differently, to some it encourages their growth while in others it antagonizes and leads to their death. Microbes found in food products occur through several means including exposure, handling, use of contaminated utensils for preparation. Several groups of bacteria (coliforms, lactic acid bacteria, aerobic bacteria etc) and fungi participate in the fermentation of steeped grains for $O g i$ production.

Maize had the highest \% moisture content $(9.22 \%)$ and lowest in sorghum $(7.11 \%)$. The lower moisture content value of the sorghum indicates its higher keeping quality than the other cereals under consideration. This is because moisture is important for the proliferation of food-spoiling microorganisms. Scientific investigation has reported that low moisture content in food samples increased the storage periods of the food products [19]; while high moisture content in foods encourage microbial growth; hence, food spoilage [20]. Protein was highest in millet $(12.11 \%)$ followed by sorghum $(11.03 \%)$ and lowest in maize $(9.01 \%)$ implying that the cereals are not devoid of protein as many people presume. This implies that the cereal-based $O g i$ also contain reasonable amounts of body building nutrient. This is similar to the percentage protein content in the range of 8.58-12.39\% as reported by Izah et al. [15].

A study also found the percentage protein content of three maize varieties grown in Nigeria in the range of 10.67$11.27 \%$ for the maize grains [21] while another reported mean percentage protein content of $10.8 \%, 11.1 \%$ and $10.5 \%$ for the maize samples analyzed [22]. Oko et al. [23] reported protein content ranging from 1.17- 7.94\% among 20 varieties of rice, with a mean value of $4.99 \pm 1.37 \%$. The protein composition of whole wheat flour ranged from 10.13 to $14.74 \%$ among different Pakistani wheat varieties as reported by Khan and Zeb [24]. Three sorghum varieties analyzed by Mustapha et al. [25] revealed that the protein ranged from 14.51 to $14.80 \%$. According to Pearson [26], plant foods that provide more than $12 \%$ of its calorific value from protein are considered good source of protein.

Highest crude fat (oil) content was exhibited by maize $(2.54$ $\%)$ and lowest in millet $(2.32 \%)$. This low percentage of crude fat indicates that prolonged storage of the grains may not affect the quality as poor storage causes rancidity

Page $\mid 682$ 
(peroxidation of polyunsaturated fatty acid) that would impact unpleasant odour and reduced intake of food and nutrient. In a study conducted by Ikram et al. [27] to determine fat content of maize, values ranged between $3.21 \%$ and $7.71 \%$. Similarly, the results on sorghum by Mustafa et al. [25] revealed a range of 3.58 to $4.47 \%$.

Fat contributes to the energy value of these grains, thereby providing essential fatty acids for optimum neurological, immunological and functional developments in children [15]. In the case of crude fibre in this study, millet was highest $(3.76 \%)$ followed by maize $(3.03 \%)$ and sorghum $(2.15 \%)$. The high fibre content of these samples can have some biological beneficial effects such as laxative effect on the gastrointestinal tract (GIT), increased faecal bulk and reduction in plasma cholesterol level [28]. Studies have shown that percent crude fibre ranged from $0.80-2.32 \%$ [27].

Ijabadeniyi and Adebolu [21] reported slightly higher values $(2.07-2.77 \%)$ of the fibre content for the maize varieties grown in Nigeria. Iken et al. (2002) observed that the average crude fibre value for the Improved White Dent (IWD), Improved Yellow Flint Dent (IYFID) and Local Floury (LF) varieties was lower than the average value of 9.5\% as reported by Watson [29]. The Proteins Advisory Group [30] of the United Nations suggested an upper limit of $5.0 \%$ crude fibre in supplementary foods. Thus, the values obtained in this study $(2.15-3.76 \%)$ fell within the recommended ranges for infants.

The ash content, which is an index of mineral contents, was found in the range of $1.77 \%$ to $2.53 \%$. Millet, having the highest value contained a greater proportion of nonendosperm material because ash values indicate the level to which non-endosperm components are present [31]. Carbohydrates are the major food component of the grains. It was found in the range of $71.30 \%$ for sorghum to 74.89 $\%$ for maize. Ikram et al. [27] observed that carbohydrates are the major chemical components of the maize grains as they reported a range of 69.659-74.549\%. Ijabadeniyi and Adebolu [21] reported slightly lower values (65.63-70.23 $\%$ ) of the carbohydrate content for the maize varieties grown in Nigeria. Carbohydrate in sorghum was reported by Mustafa et al. (2003) to be between 68.34 to $69.65 \%$. The principal carbohydrate of all cereals is starch, representing $56 \%$ (oats) to $80 \%$ (maize) of the grain dry matter [32].

FAO reported that staple foods such as millet, maize and sorghum are high in starch which makes them absorbed a lot of water during cooking. This makes them bulky and, hence, infants need to consume large quantities to get www.ijeab.com enough energy and nutrients but it is difficult because they have small stomach. The problem is, however, solved if families feed children with weaning foods prepared from germinated cereal flour and enrich bulky foods. Malting reduces viscosity of the foods and hence a child can eat more at a time $[33,34]$.

Mineral compositions of the samples were shown in Table 3. The Ca composition ranged from 10.11 to $28.92 \mathrm{mg} / 100$ g. The Zinc ( $\mathrm{Zn}$ ), Sodium (Na), Iron (Fe), Magnesium (Mg) and Potassium $(\mathrm{K})$ compositions in the three cereal-based Ogi ranged from 7.87 to $9.72 \mathrm{mg} / 100 \mathrm{~g}, 302.37$ to 352.33 $\mathrm{mg} / 100 \mathrm{~g}, 45.77$ to $52.63 \mathrm{mg} / 100 \mathrm{~g}, 80.01$ to $99.33 \mathrm{mg} / 100$ $\mathrm{g}$ and 310.20 to $426.08 \mathrm{mg} / 100 \mathrm{~g}$, respectively. According to FAO/WHO [35], minerals such as iron and zinc are low in cereals but the addition of legumes can improve the iron content. Cereals that are particularly rich in iron and calcium will be useful in reducing prevalence of iron deficiency and assist in bone development in children respectively. Potassium helps maintain fluid balance, and high intake improves blood pressure, according to the American Heart Association [36].

\section{CONCLUSION}

The results will clear the air as regards the preferences of consumers as to which of the products possesses best nutritional benefits based on the type of cereal grain used for the preparation of the product. This study revealed the distribution of fermentative microorganisms and some contaminants which were not directly associated with fermentation of the cereal grains for production of $O g i$. There were no significant differences in the proximate and elemental compositions of the maize-, millet- and sorghumbased pap $(O g i)$. The study showed significantly acceptable percentage compositions of crude protein, fibre, ash, fat and carbohydrate. Low moisture content and persistence of lactic acid bacteria in the products are considered responsible for the prolonged shelf-life the products are known for. The variations in elemental compositions of the three cereal grains were not also significant. However, maize-, millet- and sorghum-based $O g i$ could be fortified with products of higher nutrient composition to increase the acceptability of the diet among people of all ages and classes.

\section{AUTHOR CONTRIBUTIONS}

$\mathrm{OOB}$ and TKB conceived and designed the experiments; OOB and OTA performed the experiments; OOB analyzed the data; YOA contributed reagents/materials/analysis tools; 
OOB wrote the paper. All authors read and approved the final manuscript.

\section{REFERENCES}

[1] Osho, A., Mabekoje, O. O. and Bello, O. O. (2010). Comparative study on the microbial load of Gari, Elubo-isuand Iru in Nigeria. African Journal of Food Science, 4(10), 646 - 649.

[2] Bello, O. O. Bankole, S. A. and Babalola, O. O. (2016). Molecular screening of bacteriocin produced by lactic acid bacteria from Irvingiagabonensis seeds. Nature and Science, 14(8), 67-78

[3] Badmos, A. H. A., Kayode, R. M. O. and Amali, H. E., Ahmed, O. and Adeyemi, K. O. (2014). Fermentation andWest African food culture. Global Journal of Bio-Science and Biotechnology, 3(2), 128132.

[4] Kohajdová, Z. and Karovičová, J. (2007). Fermentation of cereals for specific purpose. Journal of Food andNutrition Research, 46(2), 51- 57.

[5] Ikya, J. K., Gernah, D. I. and Sengev, I. A. (2013). Proximate composition, nutritive and sensory properties offermented maize, and full fat soy flour blends for "agidi" production. African Journal of Food Science, 7(12),446-450.

[6] Akinleye, O. M., Fajolu, I. O., Fasure, A. K., Osanyinpeju, O. S., Aboderin, A. O. and Salami, O. O. (2014). Evaluation of microorganisms at different stages of production of Ogi in Alimosho Community, Area Southwest, Lagos, Nigeria. American Journal of Research Communication, 2(10), 215-230.

[7] Adegbehingbe, K.T. Fermented sprouted and unsprouted maize for Ogi production. International JournalofAdvanced Research, 2013, 1(10), 428-434.

[8] Bolaji, O.T.; Oyewo A.O.; Adepoju, P.A. Soaking and drying effect on the functional properties of Ogi produced from some selected maize varieties. American Journal of Food Science and Technology, 2014, 2(5), 150-157.

[9] Omemu, A. M. and Omeike, S. O. (2010). Microbiological hazard and critical control points identification during household preparation of cooked Ogi used as weaning food. International Food Research Journal, 17,257-266.

[10] Abioye, V. F. and Aka, M. O. (2015). Proximate composition and sensory properties of moringa fortified maize- Ogi. Journal of Nutrition and Food Sciences, 2015, S12 http://dx.doi.org/10.4172/21559600.S12-001.

www.ijeab.com
[11] Schillinger, U. and Lucke, F. K. (1987). Identification of lactobacilli from meat and meat products. FoodMicrobiology, 4, 199-208

[12] Schipper, M. A. A. (1984). A revision of the genus Rhizopus. The Rhizopusstolonifer group and Rhizopusoryzae.Studies in Mycology, 25, 1-19.

[13] Hesseltine, C.W. (1991). Zygomycetes in food fermentations. Mycologist. 5 (4), 162-169.

[14] Hussain, J., Khan, A., Rehman, N., Hamayun, M., Shah, T., Nisar, M., Bano, T., Shinwari, Z. K. and Lee, I. (2009). Proximate and nutrient analysis of selected vegetable species. A case study of Karak Region Pakistan. African Journal of Biotechnology, 8(12), 2725-2729.

[15] Izah, S. C., Kigigha, L. T. and Okowa I. P. (2016). Microbial quality assessment of fermented maize Ogi (a cereal product) and options for overcoming constraints in production. Biotechnological Research, 2(2), 81-93.

[16] Oyelana, O. A. and Coker, A. A. (2012). Microbial contamination at different stages of production of Ogi inMowe: a rural community, Southwestern Nigeria. Bacteriology Journal, 2(1), 1 -11.

[17] Wakil,S. M.and Daodu, A. A. (2011). Physiologicalproperties of a microbial community in spontaneous fermentation of maize (Zea mays) for Ogi Production. International Research Journal of Microbiology 2011,2(3), 109-115.

[18] Adesokan, I. A., Abiola, O. P. and Ogundiya, M. O. (2010). Infleunce of ginger on sensory properties and shelf- life of Ogi, a Nigerian traditional fermented food. African Journal of Biotechnology, 9(12), 1803 1808.

[19] Alozie, Y. E., Iyam, M. A., Lawal, O., Udofia, U. and Ani, I. F. (2009). Utilization of Bambara ground flour blends in bread production. Journal of Food Technology, 7(4), 111-114.

[20] Temple, V. J., Badamosi, E. J., Ladeji, O. and Solomon, M. (1996). Proximate chemical composition of three locally formulated complementary foods. West African Journal of Biological Sciences, 5,134143.

[21] Ijabadeniyi, A. O. and Adebolu, T. T. (2005). The effect of processing methods on the nutritional properties of Ogi produced from three maize varieties. Journal of Food, Agriculture and Environment, 3,108109.

[22] Iken, J. E., Amusa, N. A. and Obatolu, V. O. (2002). Nutrient composition and weight evaluation of some

Page | 684 
newly developed maize varieties in Nigeria. Journal of Food Technology in Africa, (7), 27-29.

[23] Oko, A. O.; Ubi, B. E.; Efisue, A. A. and Dambaba, N. (2012). Comparative analysis of the chemical nutrient composition of selected local and newly introduced rice varieties grown in Ebonyi State of Nigeria. International Journal of Agriculture and Forestry, 2(2), 16-23.

[24] Khan, I. and Zeb, A. (2007). Nutritional composition of Pakistani wheat varieties. Journal of Zhejiang University.Science B, 8, 555-559.

[25] Mustafa, A. A. and Magdi, A. (2003). Proximate composition and the content of sugars, amino acids and anti- nutritional factors of three sorghum varieties. Res. Bult., No. (125), Agricultural. Research Center, King Saud University. 2003;5-19.

[26] Pearson D. (1976). The chemical analysis of foods, 17th ed., Churchill Living Stone, London. 3-4.

[27]Ikram, U., Muhammad, A. and Arita, F. (2010). Chemical and nutritional properties of some maize (Zea mays L.)varieties grown in NWFP, Pakistan. Pakistan Journal of Nutrition, 9(11), 1113-1117.

[28] Okoye, Z.S.C. (1992). Biochemical aspects of nutrition. Prentice-Hall of India, New Delhi., 147195.

[29] Watson, S. A. (1987). Structure and composition. In: corn chemistry and Technology. Watson SA, Ramstand PE (eds) Amer. Ass. General chem., USA. 1987, 53.

[30] Proteins Advisory Group (1975). Guideline on protein-rich mixtures for use as supplemental foods. The pag compendium vol. E. Worldmark Press Ltd., John Wiley and Sons, New York, 63.

[31]Evers, A. D. (2012). Ash determination - a useful standard or a flash in the pan; 2001. Retrieved on October 20,2012. Available: http://www.satakeeurope.com

[32] Eliasson, A. C. and Larsson, K. (1993). Cereals in bread making. New York, Marcel Dekker, Inc. 1993, 376

[33]FAO. (2001). Improving nutrition through home gardening, a training package for preparing field workers inAfrica, FAO Rome.

[34] Ikujenlola, V. A. and Fashakin, J. B. (2005). The Physicochemical properties of a complementary diet prepared from vegetable proteins. Journal of Food Agricultural Environment, 3(3 and 4), 23-26.

[35]FAO/WHO (2001). Human vitamin and mineral requirements, Report of a joint $\mathrm{FAO} / \mathrm{WHO}$ expert www.ijeab.com consultation, Bangkok Thailand, Food and Nutrition Division, FAO Rome, 7-8.

[36] Corleone J. (2012). Nutritional and therapeutic values of guinea corn, Demand Media, Inc; 2011. Retrieved on October 20,

Available:www.livestrong.com/article/474074. 